\title{
Role of Natalizumab in Relapsing-Remitting Multiple Sclerosis: A review.
}

Anuj Krishna Paudel ${ }^{1}$, Sanjiv Bastakoti ${ }^{2}$, Nitesh Raj Dulal ${ }^{3}$, Gunja Piya ${ }^{4}$, Sashi Bhusan Singh ${ }^{5}$

Medical Officer, ${ }^{1}$ Metrocity Hospital and Research Center, Pokhara, ${ }^{2}$ Arughat Hospital, Gorkha, ${ }^{3}$ Bharatpur District Hospital,

Bharatpur, ${ }^{4}$ College of Medical Sciences, Bharatpur, ${ }^{5}$ KIST Medical College and Teaching Hospital, Kathmandu.

Received: February 15, 2021

Accepted: March 05, 2021

Published: March 30, 2021

Cite this paper:

Paudel AK, Bastakoti S, Dulal NR, Piya G, Singh SB. Role of Natalizumab in Relapsing-Remitting Multiple Sclerosis: A review. Journal of Brain and Spine Foundation Nepal. 2021:2(1):2-12.

Correspondence:

Anuj Krishna Paudel

Medical Officer

Metrocity Hospital and Research Center, Pokhara, Nepal.

Email: anuzpaudel@gmail.com

ORCID: http://orcid.org/0000-0003-1321-77658.

\begin{abstract}
:
Introduction: Multiple sclerosis is a non-traumatic neurological disease caused by an immune-mediated reaction leading to a chronic inflammatory demyelinating disorder of the central nervous system. The treatments for multiple sclerosis are mainly divided into three categories: treatment of exacerbation, slowing disease progression with disease-modifying therapies, and symptomatic therapies. Natalizumab is a monoclonal antibody that works by preventing the adhesion of lymphocytes into the endothelium of the blood-brain barrier, reducing lymphocyte infiltration into the central nervous system. This review aims to study the efficacy and safety of natalizumab in relapsing-remitting multiple sclerosis. Methods: The review was performed using databases like PubMed, Cochrane library, Google scholar from which 48 relevant articles were selected based on the various inclusion criteria. The following keywords were used: "Natalizumab", "Multiple sclerosis", "side effects", "Relapsing-remitting multiple sclerosis", "progressive multifocal leukoencephalopathy" in different combinations. Results: The literature review suggests that natalizumab reduces the rate of sustained progression of the disease and disability, and was associated with a lower relapse rate in patients with relapsing-remitting multiple sclerosis. However, Progressive multifocal leukoencephalopathy is one of the serious side effects of natalizumab. Conclusion: The literature review suggests that Natalizumab has favorable outcomes in patients with relapsing-remitting multiple sclerosis. Since progressive multifocal leukoencephalopathy is one of the serious side effects of natalizumab, risk stratification should be done.
\end{abstract}

Keywords: Relapsing-Remitting Multiple Sclerosis, Progressive multifocal leukoencephalopathy, Natalizumab.

\section{Introduction:}

Multiple sclerosis (MS) is an immune mediated chronic inflammatory demyelinating disorder of the central nervous system leading to damage of the axons and progressive neurodegeneration from the early stages. As of late, its incidence has been increasing worldwide. Looking at the United States Center for Disease Control and Prevention data, the prevalence of MS varies from 58 to 95 per 100,000 populations in the United States. ${ }^{1}$ The cause of MS is not known, but it has been determined that genetic and environmental factors play a role in increasing an individual's risk. Although the symptoms vary in each individual, some of the common presenting symptoms are mononuclear painful loss of vision, hemiparesis, paresthesia, urinary incontinence, vertigo, ataxia, tremors, etc. MS has been divided into four different categories as per its presentation pattern which are Relapsing remitting Multiple Sclerosis (RRMS), Secondary progressive Multiple Sclerosis (SPMS), Primary progressive Multiple Sclerosis (PPMS), Progressive relapsing Multiple Sclerosis 


\section{Paudel AK et al.: Natalizumab in Relapsing-Remitting Multiple Sclerosis}

(PRMS). RRMS is defined as an episode where there is worsening of the neurological function with total or partial recovery and no apparent progression of the disease.

The treatments for MS are mainly divided into three categories: treatment of exacerbation, slowing disease progression with disease-modifying therapies, and symptomatic therapies. Currently, more than a dozen disease-modifying therapies have been approved for the treatment of MS mostly for RRMS. Natalizumab (NTZ) is a monoclonal antibody that belongs to diseasemodifying therapy and works by preventing the adhesion of lymphocytes into the endothelium of the blood-brain barrier, reducing lymphocyte infiltration into the central nervous system. ${ }^{2}$

Since the approval of NTZ by the FDA in 2004, it has shown to be effective in the treatment of MS but with the increased risk for progressive multifocal leukoencephalopathy (PML). After three incidences of PML, NTZ was temporarily withdrawn from the market. However, due to its efficacy, NTZ was again reinstated in 2006 for the treatment of MS. ${ }^{3}$ Presently, the global incidence for PML in NTZ-treated patients is 4.08 per $1000 .^{4}$

The main objectives of this review article are to elucidate the effectiveness of NTZ in the treatment of RRMS, to review the association between MS and PML, and to determine the immunological and hematological changes after treatment with NTZ in patients with MS.

\section{Methods:}

\section{Electronic source and search:}

An electronic search of literature published in English was carried out using PubMed, Cochrane Library, and Google Scholar. The search was done using the keywords like "Natalizumab", "Multiple sclerosis", "side effects", "relapsing-remitting multiple sclerosis", "progressive multifocal leukoencephalopathy" in different combinations. The inclusion criteria for the articles in this review were articles based on human studies, ease of accessibility of the article, published in English literature within the year 2005-2020, and adults of age more than 18 having MS.

\section{Results:}

Initially, 65 original articles were selected from the search based on the inclusion criteria out of which five articles were duplicates. After removing the duplicates, 60 articles were assessed by full-text review out of which 48 articles were found relevant and those 48 articles were used for research.

\section{Discussion:}

\section{Role of Natalizumab in Relapsing-Remitting Multiple Sclerosis}

NTZ consists of neutralizing humanized monoclonal antibodies against leukocyte integrin which suppresses the entry of leukocytes in the central nervous system by blocking leukocyte integrin. For those patients who have RRMS, there are several treatment options including corticosteroids, immunosuppressive therapies, and NTZ.

Nine hundred and forty-two patients in a two-year phase three clinical trial evaluating the efficacy and safety of NTZ in RRMS (AFFIRM) were randomly assigned out of which 627 received NTZ and 315 patients received placebo every four weeks for two years. Natalizumab reduced sustained progression of disability by $42 \%$ over the two years $(p<0.001)$. The cumulative probability of progression was $17 \%$ in the NTZ group compared to $29 \%$ in the placebo group. Furthermore, NTZ reduced the rate of relapse by $68 \%$ in the first year and led to an $83 \%$ reduction in the accumulation of new or enlarging hyperintense lesions in T2 MRI over two years. There 


\section{Paudel AK et al.: Natalizumab in Relapsing-Remitting Multiple Sclerosis}

were $92 \%$ fewer lesions in the NTZ treated patients as compared to patients receiving placebo. ${ }^{5}$

In the SENTINEL trial (The Safety and Efficacy of NTZ in Combination with Interferon Beta-1a in Patients with RRMS), 1171 patients with RRMS having relapses of the disease in the past year were randomly allocated into two groups. Patients either received treatment with interferon-beta and NTZ or with interferon beta and placebo. Sustained disease progression was present in $29 \%$ of the patients in the placebo group as compared to $23 \%$ of patients in the combination group (24\% relative risk reduction, $\mathrm{p}=0.002){ }^{6}$

Buetzkueven et al. evaluated the long-term efficacy and safety of NTZ in 4821 patients with RRMS. The mean annualized relapse rate decreased from 1.99 in the 12 months prior to the baseline to 0.31 after NTZ therapy $(\mathrm{p}<0.0001)$ remaining low even after five years. A lower annualized relapse rate was observed in patients who used NTZ as a first therapy for MS. ${ }^{7}$

In a systematic review and meta-analysis by Prosperini et al, post-NTZ disease reactivation in RRMS was studied. 35 articles were included in the study. Clinical relapses were seen in $9-80 \%$ of the patients and $7-87 \%$ of patients revealed the radiological evidence of disease activity starting after six weeks of discontinuation of NTZ. The meta-analysis of six articles including 1183 patients showed younger age at the onset of disease, presence of disease activity in MRI before the start of treatment, and fewer NTZ infusions were associated with an increased risk of post-NTZ disease reactivation $(\mathrm{p}<0.05){ }^{8}$

A systematic review by Pucci et al. studied the efficacy, safety, and tolerability of NTZ in RRMS. The study showed statistically significant evidence in the favour of NTZ for both the primary and secondary outcomes. A $40 \%$ reduction in the risk of experiencing at least one exacerbation at two years and a $25 \%$ reduction in experiencing progression as compared to the control group was found. In addition, MRI parameters showed favorable outcomes for NTZ. ${ }^{9}$

In a systematic review and meta-analysis by Tsivgoulis et al, the efficacy of NTZ was compared to fingolimod (FGD) in patients with RRMS. NTZ was associated with a greater reduction in a two-year annualized relapse rate as compared to FGD. When comparing the proportions of the patients who remained relapse-free and those with disability progression at two years, no significant differences were found between both therapies. ${ }^{10}$

A study by Havla et al. recurrence of disease activity after the discontinuation of NTZ was studied in 13 patients who either did not receive disease-modifying therapy or received treatment with glatiramer acetate. It was observed that recurrence of the disease activity was found in both groups after NTZ cessation. One of the patients who had glatiramer and three patients who did not receive disease-modifying therapy had a relapse of disease. Patients with relapse had higher disease activity before the initiation of NTZ as compared to patients who did not have relapse of disease. ${ }^{11}$

In a retrospective observational study of 146 patients by Krysko et al. $72 \%$ of the patients had RRMS and the remaining 28\% had SPMS. Comparison of annualized relapse rate (ARR) and expanded disability status scale were done (EDSS) between RRMS and secondary progressive MS (SPMS). There was a $76 \%$ reduction in ARR in RRMS patients as compared to a $68 \%$ reduction in SPMS patients. Although there was an $11 \%$ reduction in EDSS in RRMS patients, there were no significant changes in EDSS in SPMS patients. ${ }^{12}$

In a study by Sargento-Freitas et al. 48 patients with MS who were treated with NTZ for at least 12 months were included. The variables with optimal response were an 


\section{Paudel AK et al.: Natalizumab in Relapsing-Remitting Multiple Sclerosis}

age of 37.5 years or less at the first administration of NTZ, a baseline EDSS score of 4.5 or less, disease duration of 9.5 years or less, progressive-phase duration of 9.5 years or less in patients with SPMS and ARR in the previous year of at least two. Responsiveness to treatment with NTZ was not associated with characteristics of the disease at the onset indicating that patients with highly active disease and low disability were ideal candidates for NTZ treatment. ${ }^{13}$

Results of the various studies showed NTZ to be effective for RRMS by reducing the rate of sustained progression of the disease and the rate of clinical relapse. ${ }^{7,9}$ The effect of NTZ on reducing the ARR and EDSS progression was further highlighted by the study done by Butzkueven where treatment with NTZ was associated with a lower relapse rate and it helped to stabilize disability levels in patients with RRM. ${ }^{7}$ Some patients experience disease reactivation post-NTZ treatment. A study done by Prosperini et al. showed younger age at the onset of disease and the presence of disease activity in MRI before the treatment with NTZ was associated with disease reactivation. ${ }^{8}$ However, the lower age of the onset of disease, and limited disability were considered to be favorable outcomes by SargentoFreitas et al. ${ }^{13}$ FDA has approved various drugs for the treatment of RRMS. ${ }^{14}$ Interferon and Glatiramer Acetate are present in the injectable forms and Fingolimod are therapeutic options available in oral form. In addition, various immunotherapies such as Alemtuzumab and Rituximab are available in the infusion forms. Tsivgoulis et al showed that in terms of indirect analysis of RCT data, NTZ might be more effective than oral Fingolimod in reducing disease activity in patients with RRMS. ${ }^{10}$ Discontinuation of NTZ might be associated with disease reactivation which was further highlighted by Havla et al and thus patients require treatment with other available options after discontinuation of NTZ. ${ }^{11}$
Diseases like MS can affect the quality of life, however, studies by Krysko et al showed NTZ can have beneficial outcomes to improve quality of life in patients with MS in addition to the reduction of relapse rate and stabilization of EDDS. ${ }^{12}$ Table number one (1) shows various studies that revealed an association between NTZ and RRMS.

\section{Safety of Natalizumab in Multiple sclerosis:}

1. Progressive Multifocal Leukoencephalopathy (PML) The major concern about the use of NTZ is PML. It is a rare but severe opportunistic brain infection of the brain caused by the reactivation of a polyomavirus, the John Cunningham (JC) virus. The virus is present latent in about $50-70 \%$ of the population, mostly in the kidneys. The major risk factors for PML on NTZ therapy are antiJCV positive status, prior immunosuppressant use, and duration of NTZ therapy. ${ }^{15}$ The clinical features of a classic PML include altered mental status, motor deficits (hemiparesis or monoparesis), limb ataxia, gait ataxia, and visual symptoms such as hemianopia and diplopia. It may be asymptomatic in an earlier stage and symptoms may vary from patient to patient depending upon the location of the lesion in the brain; it typically spares the optic nerve and the spinal cord. The MRI classically shows hyper-intense lesions in T2-weighted and fluidattenuated inversion recovery (FLAIR) images with hypointensity seen on T1-weighted images. Although contrast enhancement has been reported in about $40 \%$ of cases of NTZ-associated PML, the PML lesions typically do not show contrast enhancement. ${ }^{16,17}$ Lesions are often multifocal and are present in frontal and parieto-occipital regions of the brain, but solitary lesions can be found anywhere in the brain. The diagnosis of PML is made based on history, imaging, and polymerase chain reaction (PCR) testing of cerebrospinal fluid (CSF). PML has a very bad prognosis with a high fatality 


\section{Paudel AK et al.: Natalizumab in Relapsing-Remitting Multiple Sclerosis}

rate. The factors associated with improved survival are younger age, lower viral load, and more localized brain involvement, while old age and higher viral load are associated with poor survival. ${ }^{2}$ Early detections of PML with MRI monitoring prior to the onset of symptoms have been associated with good prognosis and outcome compared with PML diagnosed after symptom onset. ${ }^{18}$

The SENTINEL study was halted one month early on February 28, 2005, due to reports of PML in NTZ-treated patients. One of these patients was enrolled in SENTINEL and another was participating in an openlabel safety study of NTZ and IFN beta-1a after completing SENTINEL. A third PML patient was discovered after postmortem analysis of a NTZ-treated patient with Crohn's disease who had mistakenly received a diagnosis of astrocytoma. SENTINEL study was suspended and the drug was also temporarily removed from the market. A global risk-management program was then created to develop a risk stratification paradigm for PML. 6

The Tysabri Global Observational Program in Safety (TYGRIS) study is a large post-marketing observational study. ${ }^{19}$ The study prospectively followed 4938 patients with MS to determine the rate of serious adverse events. In the study, PML was seen in three out of 2207 US patients and 41 out of 4227 European/Canadian patients. In 23 out of total PML cases, anti-JCV antibody status was positive for six or more months prior to PML diagnosis. ${ }^{20,21}$ The antibody status in the other 21 cases was unknown or not reported. Serious opportunistic infections such as tuberculosis, candida pneumonia, aspergillosis, atypical mycobacterial infection, cryptococcal infection, and herpetic meningoencephalitis were seen in 11/6434 patients. There were 77 deaths reported, $94.8 \%$ of deaths were considered not related or unlikely to be due to NTZ. ${ }^{20}$
The Tysabri Observational Programme (TOP), is a 10 year (2007-2017) long open-label multinational prospective observational study evaluating the long-term safety and effectiveness of Natalizumab in RRMS. The study included 6148 patients, out of which 829 patients (13.5\%) experienced one or more serious events, with infection being the most common $(4.1 \%)$. In the entire cohort, 53 patients $(0.9 \%)$ had confirmed PML. PML patients received a median of 42 doses or months of exposure (range 11-124); 36 of 53 PML cases $(67.9 \%)$ occurred in patients receiving NTZ for more than three years. The overall PML incidence rate per 1000 patientyears was 2.034 (95\% CI 1.554 to 2.662). Prior immunosuppressant use was reported by 14 PML patients $(26.4 \%)$. Of the $36 \mathrm{PML}$ cases with reported anti-JCV antibody serostatus available six months prior to PML development, 35 (97.2\%) were confirmed positive. $^{22}$

A review study was carried out in 2012 to study the relationship between NTZ and PML according to the anti-JC virus positivity status, prior use of immunosuppressants, and the duration of the NTZ therapy. In the study, 99,571 patients were treated with NTZ out of which there were 212 confirmed cases of PML (2.1/1000 patients). In 54 patients with PML for whom samples were available before the diagnosis were positive for anti-JC virus antibodies. The risk of PML was stratified according to three risk factors; the risk of PML was lowest among the patients who were negative for anti-JC virus antibodies, with the incidence estimated to be $\leq 0.09 / 1000$ patients (95\% CI, 0-0.48). Patients who were positive for anti-JC virus antibodies, had taken immunosuppressant's before the initiation of NTZ therapy, and had received 25 to 48 months of NTZ treatment had the highest estimated risk (incidence, 11.1 cases/1000 patients ,95\% CI, 8.3 to 14.5$){ }^{23}$ 


\begin{tabular}{|c|c|c|c|c|}
\hline Reference & Study Design & Aim of the study & Sample size & Results \\
\hline $\begin{array}{l}\text { Butzkueven } \\
\text { et al. } 2013\end{array}$ & $\begin{array}{l}\text { Open-label, } \\
\text { multinational, } \\
\text { 10-year } \\
\text { prospective } \\
\text { study }\end{array}$ & $\begin{array}{l}\text { To evaluate the long- } \\
\text { term safety of NTZ and } \\
\text { its impact on } \\
\text { annualized relapse rate } \\
\text { and Expanded } \\
\text { Disability Status Scale } \\
\text { progression in RRMS }\end{array}$ & $\begin{array}{l}4821 \text { patients were } \\
\text { enrolled }\end{array}$ & $\begin{array}{l}\text { NTZ is associated with } \\
\text { lower rate of relapse and } \\
\text { stabilized disability levels in } \\
\text { patient with RRMS }\end{array}$ \\
\hline $\begin{array}{l}\text { Prosperini et } \\
\text { al. } 2019\end{array}$ & $\begin{array}{l}\text { Systematic } \\
\text { review and } \\
\text { meta-analysis }\end{array}$ & $\begin{array}{l}\text { To identify which } \\
\text { patients will experience } \\
\text { post-NTZ disease } \\
\text { reactivation }\end{array}$ & $\begin{array}{l}35 \text { articles were } \\
\text { included in the } \\
\text { systematic review and } \\
\text { six articles were used } \\
\text { in the meta-analysis. }\end{array}$ & $\begin{array}{l}\text { Younger age of the onset, } \\
\text { presence of disease activity } \\
\text { in MRI before the start of } \\
\text { treatment, and fewer NTZ } \\
\text { infusions were associated } \\
\text { with an increased risk of } \\
\text { post-NTZ disease } \\
\text { reactivation }\end{array}$ \\
\hline $\begin{array}{l}\text { Pucci et al., } \\
2011\end{array}$ & $\begin{array}{l}\text { Systematic } \\
\text { review }\end{array}$ & $\begin{array}{l}\text { To study the efficacy, } \\
\text { safety, and tolerability } \\
\text { of NTZ in RRMS. }\end{array}$ & $\begin{array}{l}\text { One placebo- } \\
\text { controlled trial and } \\
\text { two add-on placebo- } \\
\text { controlled trial }\end{array}$ & $\begin{array}{l}\text { A reduction in relapses and } \\
\text { disability at Two years in } \\
\text { RRMS patients treated with } \\
\text { NTZ }\end{array}$ \\
\hline $\begin{array}{l}\text { Tsivgoulis } \\
\text { et al., } 2016\end{array}$ & $\begin{array}{l}\text { Systematic } \\
\text { review and } \\
\text { meta-analysis }\end{array}$ & $\begin{array}{l}\text { To compare the } \\
\text { efficacy of NTZ with } \\
\text { fingolimod in patients } \\
\text { with RRMS. }\end{array}$ & $\begin{array}{l}\text { Three Randomized } \\
\text { Controlled trials } \\
(2498 \text { patients) and } \\
\text { five observational } \\
\text { studies } \quad(2576 \\
\text { patients). }\end{array}$ & $\begin{array}{l}\text { Indirect analyses of RCT } \\
\text { data and head-to-head } \\
\text { comparisons } \\
\text { observational findings } \\
\text { indicate that NTZ may be } \\
\text { more effective than FGD in } \\
\text { terms of disease activity } \\
\text { reduction in patients with } \\
\text { RRMS. }\end{array}$ \\
\hline Havla et al. & $\begin{array}{l}\text { Prospective } \\
\text { study }\end{array}$ & $\begin{array}{l}\text { To study the } \\
\text { recurrence of disease } \\
\text { activity after the } \\
\text { discontinuation of } \\
\text { NTZ. }\end{array}$ & $\begin{array}{l}\text { Thirteen patients who } \\
\text { stopped NZ and either } \\
\text { did not receive any } \\
\text { disease-modifying } \\
\text { therapy ( Six patients) } \\
\text { or received glatiramer } \\
\text { (Seven patients) }\end{array}$ & $\begin{array}{l}\text { Discontinuation of NTZ } \\
\text { was associated with the } \\
\text { reappearance of disease } \\
\text { activity and thus } \\
\text { necessitating } \\
\text { treatment. }\end{array}$ \\
\hline Krysko et al. & $\begin{array}{l}\text { Retrospective } \\
\text { observational } \\
\text { study }\end{array}$ & $\begin{array}{l}\text { To study the efficacy } \\
\text { and safety of NTZ }\end{array}$ & $\begin{array}{l}146 \text { patients out of } \\
\text { which } 72 \% \text { had } \\
\text { RRMS and } 28 \% \text { had } \\
\text { SPMS }\end{array}$ & $\begin{array}{l}\text { Reduction in relapse rate, } \\
\text { stabilization in EDSS and } \\
\text { improvement in quality of } \\
\text { life with NTZ. }\end{array}$ \\
\hline $\begin{array}{l}\text { Sargento- } \\
\text { Freitas et al. }\end{array}$ & $\begin{array}{l}\text { Retrospective } \\
\text { study }\end{array}$ & $\begin{array}{l}\text { To identify and } \\
\text { quantify clinical } \\
\text { predictors of an optimal } \\
\text { response to NTZ. }\end{array}$ & 48 patients with MS & $\begin{array}{l}\text { Lower age of the onset of } \\
\text { disease and limited } \\
\text { disability were associated } \\
\text { with favorable outcomes. }\end{array}$ \\
\hline
\end{tabular}




\section{Paudel AK et al.: Natalizumab in Relapsing-Remitting Multiple Sclerosis}

Incidence of PML stratified according to the risk factors. Estimates of the incidence of PML are shown, stratified according to prior or no prior use of immunosuppressant's and duration of NTZ treatment (Figure 1) and according to positive or negative status for anti-JC virus antibodies, prior or no prior use of immunosuppressant's, and duration of NTZ treatment (Figure 2).

If the patient on NTZ becomes anti- JCV positive or has a rising antibody index, then both the clinician and the patient must jointly discuss the risk versus benefit of continuing NTZ therapy. Switching to alternate diseasemodifying therapy carries the risk of worsening of symptoms and disability progression. The patient must understand the full consequences of the risk of PML, including the death versus the risk of worsening, and progression of disability. ${ }^{24}$

An observational cohort study carried out by Foley et al studied the pharmacokinetic and pharmacodynamics parameters of standard interval dosing (SID) and extended interval dosing (EID) of NTZ. Results showed lower serum concentration for EID as compared to SID (18.2 versus $35.7 \mu \mathrm{g} / \mathrm{ml}$, respectively; $\mathrm{p}<0.001$ ). The occupancy of $\alpha 4$-integrin receptor sites was more with SID than EID. Furthermore, the $\alpha 4$-integrin cell surface expression was higher for EID than SID. ${ }^{25}$ In a retrospective cohort study by Ryerson et al, included anti-JC virus antibody-positive patients $(\mathrm{n}=35,521)$. The risk of PML with NTZ in patients with MS was compared between EID and SID. Relative risk reductions were $94 \%$ and $88 \%$ in favor of EID for the primary and secondary analyses, respectively. The tertiary analysis showed no cases of PML. ${ }^{26}$ In another retrospective study by Ryerson et al the clinical effectiveness was similar in EID and SID group but four patients in the SID cohort reported having PML as compared to none in the EID group. ${ }^{27}$
Results from the study of Foley et al showed that EID of NTZ reduces the serum drug levels, the occupancy of $\alpha 4$ integrin receptor sites but increases the $\alpha 4$-integrin cell surface expression. The increase in the number of open $\alpha 4$-integrin might enhance immune surveillance and prevention of PML. Association between the clinical and statistical reduction in the risk of PML with EID of NTZ was shown by the study done by Ryerson et al. In addition, another retrospective study of Ryerson et al demonstrated that EID reduced the risk of PML without diminishing the clinical efficacy of NTZ in patients with MS.

\section{Other side-effects:}

The most frequent side effects reported in NTZ-treated MS patients include headache, urinary tract infection(UTI), lung infection, myalgia, vaginitis, abdominal pain, arthralgia, depression, diarrhea, rash, and nausea, though all these symptoms also occurred at a similar rate in placebo-treated patients. Fatigue and allergic reaction were seen more frequently in NTZtreated patients compared to placebo. Hepatotoxicity with occasional hepatic failure has also been reported with NTZ. ${ }^{2}$

Immunological and hematological changes after treatment with Natalizumab in patients with multiple sclerosis:

NTZ treatment in MS can bring certain immunological changes, can also bring variation in serum and CSF cytokines level, and may affect activation of the T-cell. Villar et al studied the cell subsets and molecules that changed in patients in MS with an optimal response to treatment. Study of intrathecal immunoglobulin synthesis and cerebrospinal fluid lymphocyte subsets in patients with MS before and one year after treatment with NTZ was done. All patients showed a decrease in cerebrospinal fluid CD4+ cells after NTZ treatment 


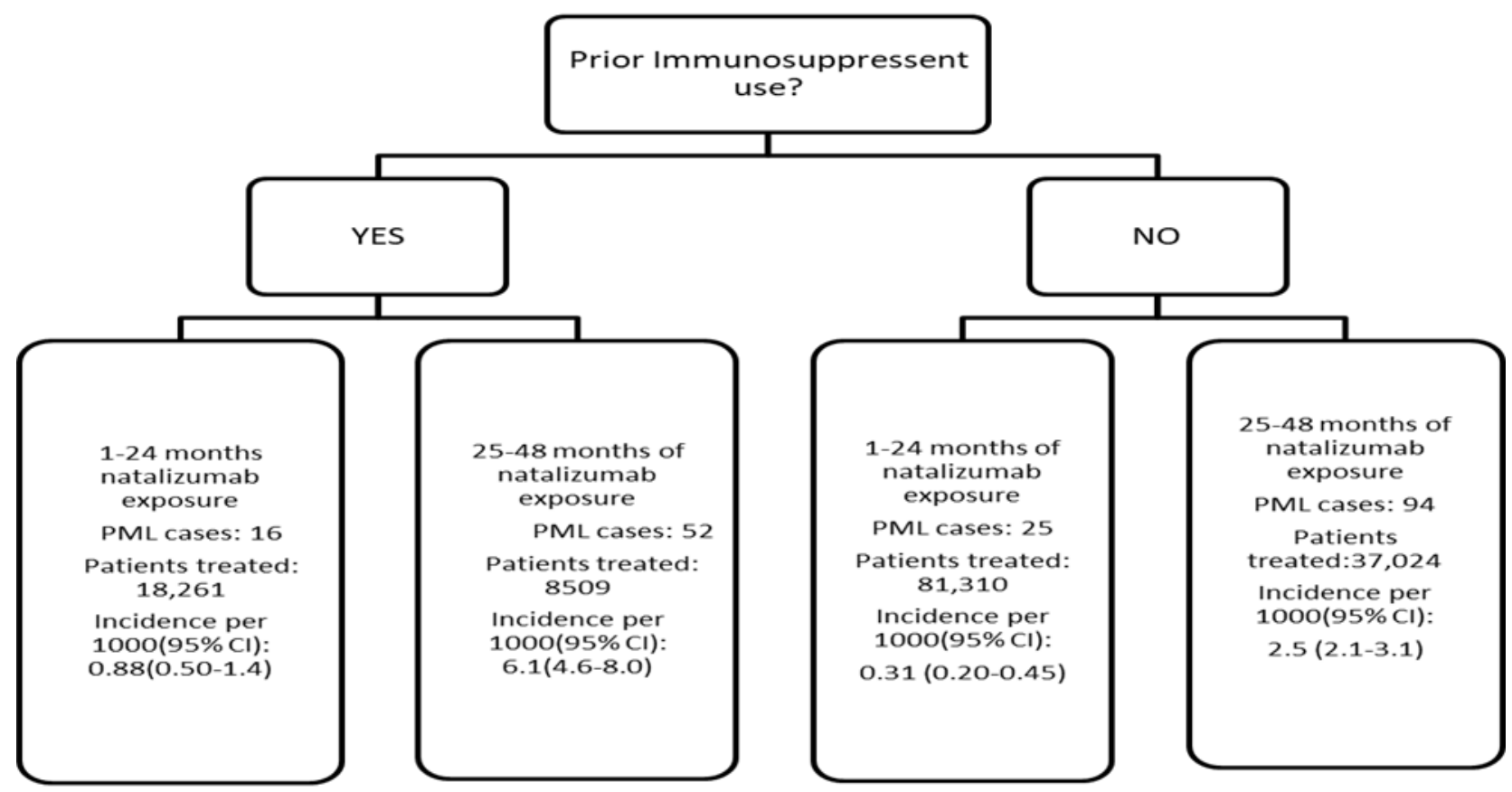

Figure 1: Estimates of the incidence of PML are shown, stratified according to prior or no prior use of immunosuppressant and duration of NTZ treatment

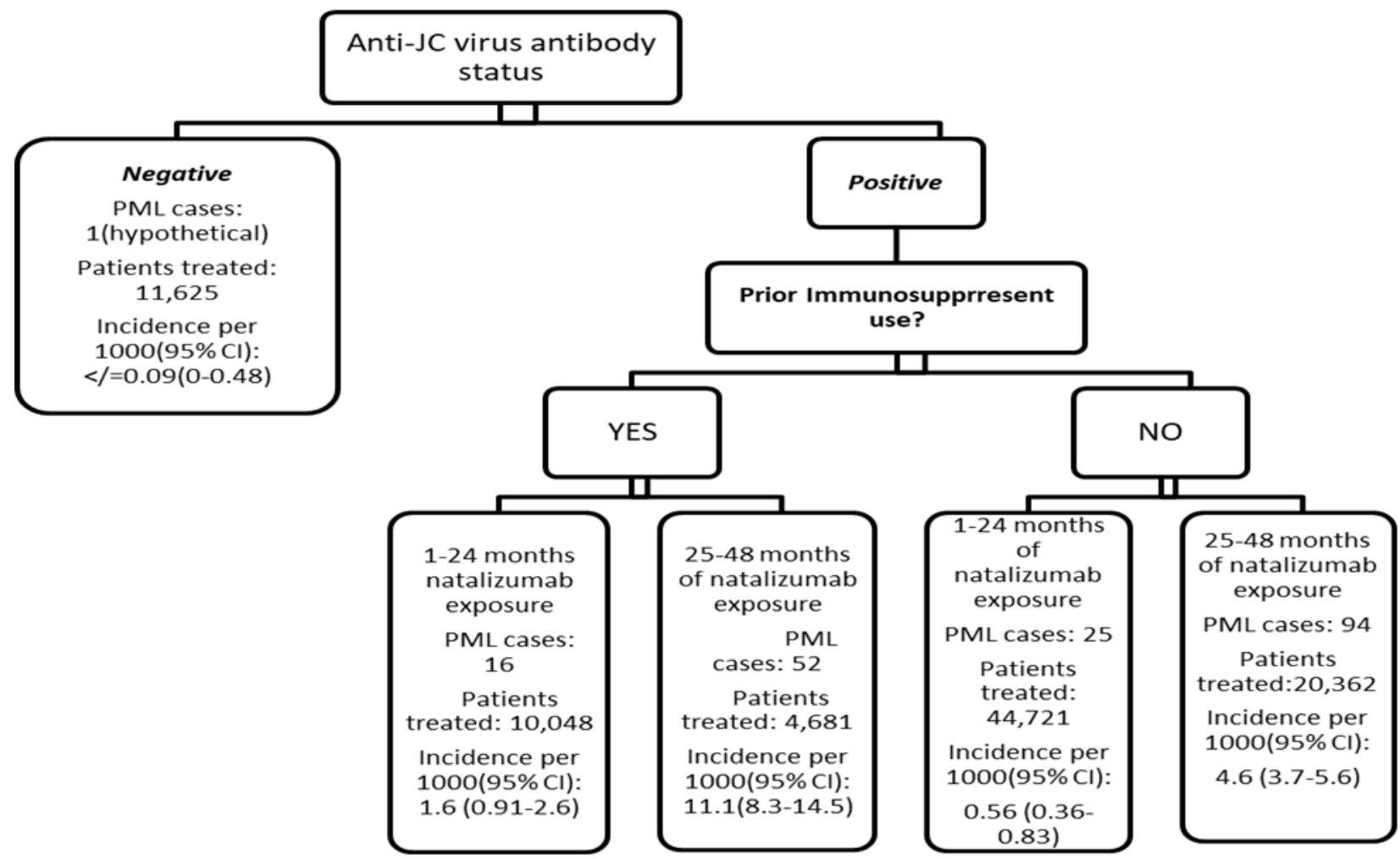

Figure $2::$ Estimates of the incidence of PML are shown, stratified according to positive or negative status with respect to anti-JC virus antibodies, prior or no prior use of immunosuppressant, and duration of NTZ treatment 


\section{Paudel AK et al.: Natalizumab in Relapsing-Remitting Multiple Sclerosis}

regardless of treatment response. However, only patients who were free of disease showed a decrease in local IgM and IgG synthesis. Lower percentages of B cells, particularly of CD5+ were noted in those patients. ${ }^{28}$ Hematopoietic mobilizations after treatment with NTZ were studied by Mattoscio et al. in a prospective study where an increased number of circulating hematopoietic stem and progenitor cells was induced by NTZ. NTZinduced hematopoietic cells were quiescent suggesting recent migration from the bone marrow. However, in patients where there was no significant mobilization of hematopoietic stem and progenitor cells, there was the persistence of disease activity and thus adding immunological and clinical relevance of mobilization. ${ }^{29}$ In a study by Skarica et al. hematological and immunological changes in 26 RRMS patients with MS were studied over 12 months. The proportions of NK cells and hematopoietic stem cells increased after NTZ treatment. Although the numbers of CD20+ B cells were increased, the proportion of CD20+ cells expressing high levels of $\alpha 4 \beta 1$ integrin was decreased. ${ }^{30}$

A study by Mattoscio et al showed that hematopoietic stem and progenitor cell mobilization is associated with remission of the disease and early hematopoietic stem and progenitor cell counts could be a biomarker predicting the responsiveness to NTZ. ${ }^{29}$ Studies suggested that NTZ decreases the number of lymphocytes in the CSF further emphasizing the concept that NTZ works by blocking the entry of lymphocytes into the central nervous system. Furthermore, inhibition of intrathecal synthesis of antibodies was associated with favorable clinical outcomes after treatment with NTZ as per the study done by Villar et al. ${ }^{28}$

Conclusions: The literature review suggested that NTZ has favorable outcomes in patients with MS. NTZ reduced the rate of sustained progression of the disease and disability, and was associated with a lower relapse rate in patients with relapsing-remitting multiple sclerosis. NTZ reduced the CSF lymphocytes count suggesting that it works by blocking the entry of lymphocytes into the central nervous system. The risk associated with NTZ therapy has also been identified, PML is the most important side effect; the risk stratification of PML with anti-JCV antibody status with index testing is a key component to guide the health care provider. Although studies suggested that NTZ was associated with better clinical outcomes in patients with MS, further studies are required to compare the longterm efficacy and safety of NTZ with newer immunomodulatory drugs.

\section{Acknowledgment:}

The authors of this article would like to thank Dr. Sanjaya Mahat and Mr. Chet Raj Regmi for their support in the preparation of the paper.

\section{Reference:}

1. Noonan CW, Williamson DM, Henry JP, Indian R, Lynch SG, Neuberger JS, et al. The Prevalence of Multiple Sclerosis in 3 US Communities. Prev Chronic Dis. 2010;7(1):A12. PMID: 20040227

2. Singer BA. The role of natalizumab in the treatment of multiple sclerosis: benefits and risks. Ther Adv Neurol Disord. 2017;10(9):327-36. https://doi.org/10.1177/1756285617716002.

3. Clerico M, Artusi CA, Di Liberto A, Rolla S, Bardina V, Barbero $\mathrm{P}$, et al. Long-term safety evaluation of natalizumab for the treatment of multiple sclerosis. Expert Opin Drug Saf. 2017;16(8):963-72. https://doi.org/10.1080/14740338.2017.1346082.

4. Kartau M, Sipilä JO, Auvinen E, Palomäki M, Verkkoniemi-Ahola A. Progressive Multifocal Leukoencephalopathy: Current Insights. Degener Neurol Neuromuscul Dis. 2019;9:109-21. https://doi.org/10.2147/DNND.S203405.

5. Polman $\mathrm{CH}, \mathrm{O}$ 'Connor PW, Havrdova E, Hutchinson M, Kappos L, Miller DH, et al. A randomized, placebo- 


\section{Paudel AK et al.: Natalizumab in Relapsing-Remitting Multiple Sclerosis}

controlled trial of natalizumab for relapsing multiple sclerosis. N Engl J Med. 2006;354(9):899-910. https://doi.org/10.1056/NEJMoa044397.

6. Rudick RA, Stuart WH, Calabresi PA, Confavreux C, Galetta SL, Radue EW, et al. Natalizumab plus interferon beta-1a for relapsing multiple sclerosis. $\mathrm{N}$ Engl J Med. 2006;354(9):911-23. https://doi.org/10.1056/NEJMoa044396.

7. Butzkueven H, Kappos L, Pellegrini F, Trojano M, Wiendl H, Patel RN, et al. Efficacy and safety of natalizumab in multiple sclerosis: interim observational programme results. J Neurol Neurosurg Psychiatry. 2014;85(11):1190-7. https://doi.org/10.1136/jnnp2013-306936.

8. Prosperini L, Kinkel RP, Miravalle AA, Iaffaldano P, Fantaccini S. Post-natalizumab disease reactivation in multiple sclerosis: systematic review and meta-analysis. Ther Adv Neurol Disord. 2019;12: 1756286419837809. https://doi.org/10.1177/1756286419837809.

9. Pucci E, Giuliani G, Solari A, Simi S, Minozzi S, Di Pietrantonj $\mathrm{C}$, et al. Natalizumab for relapsing remitting multiple sclerosis. Cochrane Database Syst Rev. 2011;(10):CD007621. https://doi.org/10.1002/14651858.CD007621.pub2.

10. Tsivgoulis G, Katsanos AH, Mavridis D, Grigoriadis N, Dardiotis E, Heliopoulos I, et al. The Efficacy of Natalizumab versus Fingolimod for Patients with Relapsing-Remitting Multiple Sclerosis: A Systematic Review, Indirect Evidence from Randomized PlaceboControlled Trials and Meta-Analysis of Observational Head-to-Head Trials. PLoS One. 2016;11(9): e0163296. https://doi.org/10.1371/journal.pone.0163296.

11. Havla J, Gerdes LA, Meinl I, Krumbholz M, Faber H, Weber $\mathrm{F}$, et al. De-escalation from natalizumab in multiple sclerosis: recurrence of disease activity despite switching to glatiramer acetate. $J$ Neurol. 2011;258(9):1665-9. https://doi.org/10.1007/s00415011-5996-y.

12. Krysko KM, O'Connor PW. The toronto observational study of natalizumab in multiple sclerosis. Can J Neurol Sci. 2011;38(3):422-8. https://doi.org/10.1017/S0317167100011811.
13. Sargento-Freitas J, Batista S, Macario C, Matias F, Sousa L. Clinical predictors of an optimal response to natalizumab in multiple sclerosis. J Clin Neurosci. 2013;20(5):659-62.

https://doi.org/10.1016/j.jocn.2012.04.022.

14. Saleem S, Anwar A, Fayyaz M, Anwer F, Anwar F. An Overview of Therapeutic Options in Relapsing-remitting Multiple Sclerosis. Cureus. 2019;11(7):e5246. https://doi.org/10.7759/cureus.5246.

15. Brandstadter R, Katz Sand I. The use of natalizumab for multiple sclerosis. Neuropsychiatr Dis Treat. 2017;13:1691-702. https://doi.org/10.2147/NDT.S114636.

16. Yousry TA, Pelletier D, Cadavid D, Gass A, Richert ND, Radue EW, et al. Magnetic resonance imaging pattern in natalizumab-associated progressive multifocal leukoencephalopathy. Ann Neurol. 2012;72(5):779-87. https://doi.org/10.1002/ana.23676.

17. Clifford DB, DeLuca A, Simpson DM, Arendt G, Giovannoni G, Nath A. Natalizumab-associated progressive multifocal leukoencephalopathy in patients with multiple sclerosis: lessons from 28 cases. The Lancet Neurol. 2010;9(4):438-46. https://doi.org/10.1016/S1474-4422(10)70028-4.

18. Carrillo-Infante C Richman S, Yu B, Wenten M, Robertson M, Philip J, et al. Functional and survival outcomes of asymptomatic progressive multifocal leukoencephalopathy in natalizumab-treated multiple sclerosis patients: 2015 update. [Internet]. [cited 2021 Jul 4]. Available from: https://onlinelibrary.ectrimscongress.eu/ectrims/2016/32nd/145623/cynthia.carrilloinfante.functional.and.survival.outcomes.of.asymptoma tic.html.

19. van Pesch V, Sindic CJ, Fernández O. Effectiveness and safety of natalizumab in real-world clinical practice: Review of observational studies. Clin Neurol Neurosurg. 2016;149:55-63. https://doi.org/10.1016/j.clineuro.2016.07.001.

20. Trampe AK, Hemmelmann C, Stroet A, Haghikia A, Hellwig K, Wiendl $\mathrm{H}$, et al. Anti-JC virus antibodies in a large German natalizumab-treated multiple sclerosis 
cohort. Neurology. 2012;78(22):1736-42. https://doi.org/10.1212/WNL.0b013e3182583022.

21. Salmen A, von Ahsen N, Trampe AK, Hoepner R, Plavina T, Subramanyam M, et al. Longitudinal analyses of anti-JCV antibody index for risk assessment of progressive multifocal leukoencephalopathy. Mult Scler J Exp Transl Clin. 2016 Jan 1;2:2055217316630008. https://doi.org/10.1177/2055217316630008.

22. Butzkueven H, Kappos L, Wiendl H, Trojano M, Spelman T, Chang I, et al. Long-term safety and effectiveness of natalizumab treatment in clinical practice: 10 years of real-world data from the Tysabri Observational Program (TOP). J Neurol Neurosurg Psychiatry. 2020;91(6):660-8. https://doi.org/10.1136/jnnp-2013-306936.

23. Bloomgren G, Richman S, Hotermans C, Subramanyam M, Goelz S, Natarajan A, et al. Risk of NatalizumabAssociated Progressive Multifocal Leukoencephalopathy. N Engl J Med. 2012;366(20):1870-80. https://doi.org/10.1056/NEJMoa1107829.

24. Prosperini L, Annovazzi P, Capobianco M, Capra R, Buttari F, Gasperini C, et al. Natalizumab discontinuation in patients with multiple sclerosis: Profiling risk and benefits at therapeutic crossroads. Mult Scler. 2015(13):1713-22. https://doi.org/10.1177/1352458515570768.

25. Foley JF, Goelz S, Hoyt T, Christensen A, Metzger RR. Evaluation of natalizumab pharmacokinetics and pharmacodynamics with standard and extended interval dosing. Mult Scler Relat Disord. 2019;31:65-71. https://doi.org/10.1016/j.msard.2019.03.017.

26. Ryerson LZ, Foley J, Chang I, Kister I, Cutter G, Metzger RR, et al. Risk of natalizumab-associated PML in patients with MS is reduced with extended interval dosing. Neurology. 2019;93(15):e1452-62. https://doi.org/10.1212/WNL.0000000000008243.

27. Zhovtis Ryerson L, Frohman TC, Foley J, Kister I, Weinstock-Guttman B, Tornatore C, et al. Extended interval dosing of natalizumab in multiple sclerosis. $\mathrm{J}$ Neurol Neurosurg Psychiatry. 2016;87(8):885-9. https://doi.org/10.1136/jnnp-2015-312940.

28. Villar LM, García-Sánchez MI, Costa-Frossard L, Espiño M, Roldán E, Páramo D, et al. Immunological markers of optimal response to natalizumab in multiple sclerosis. Arch Neurol. 2012;69(2):191-7. https://doi.org/10.1001/archneurol.2011.971.

29. Mattoscio M, Nicholas R, Sormani MP, Malik O, Lee JS, Waldman $\mathrm{AD}$, et al. Hematopoietic mobilization: Potential biomarker of response to natalizumab in multiple sclerosis. Neurology. 2015;84(14):1473-82. https://doi.org/10.1212/WNL.0000000000001454.

30. Skarica M, Eckstein C, Whartenby KA, Calabresi PA. Novel mechanisms of immune modulation of natalizumab in multiple sclerosis patients. $\mathbf{J}$ Neuroimmunol. 2011;235(1-2):70-6. https://doi.org/10.1016/j.jneuroim.2011.02.010. 